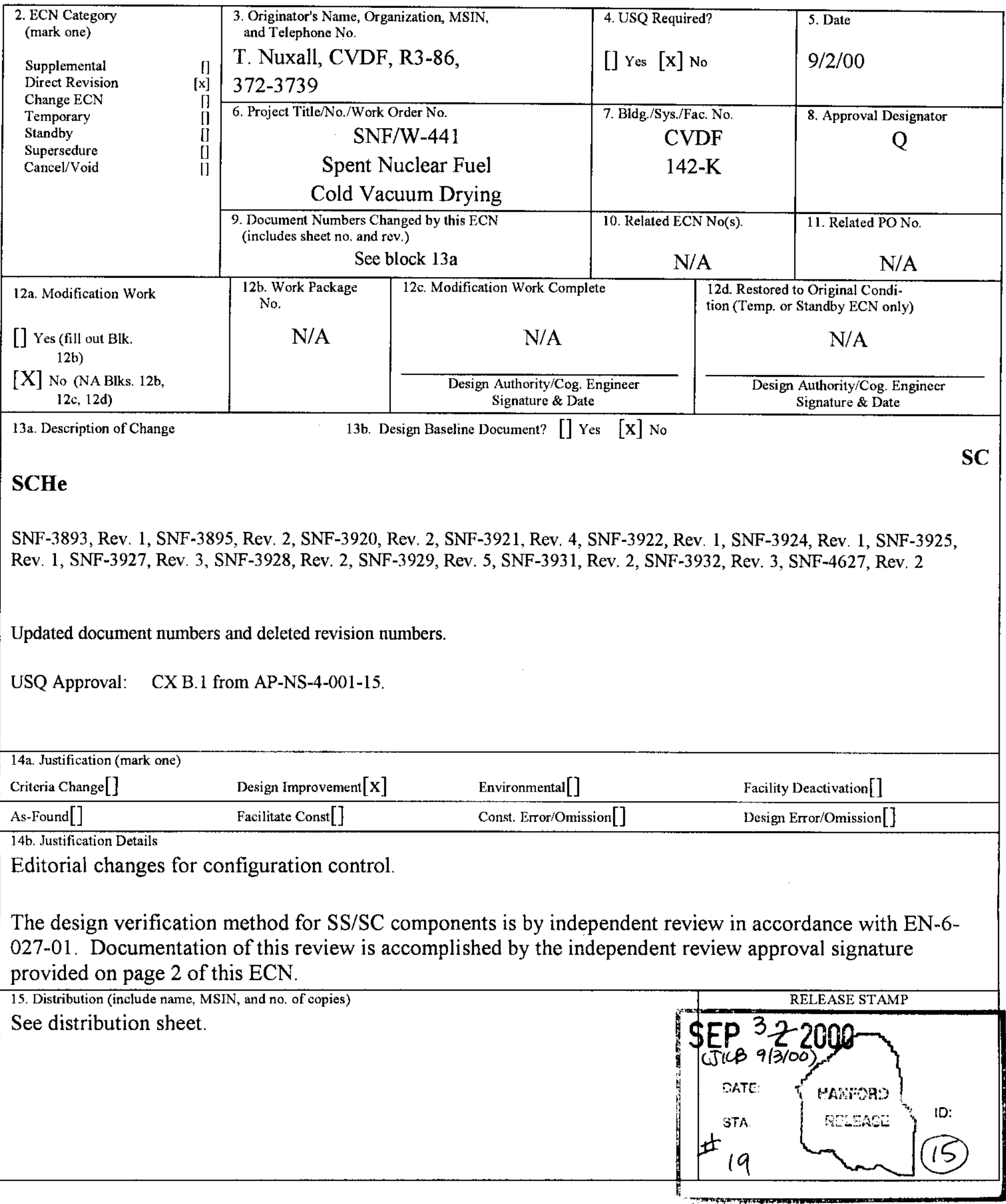




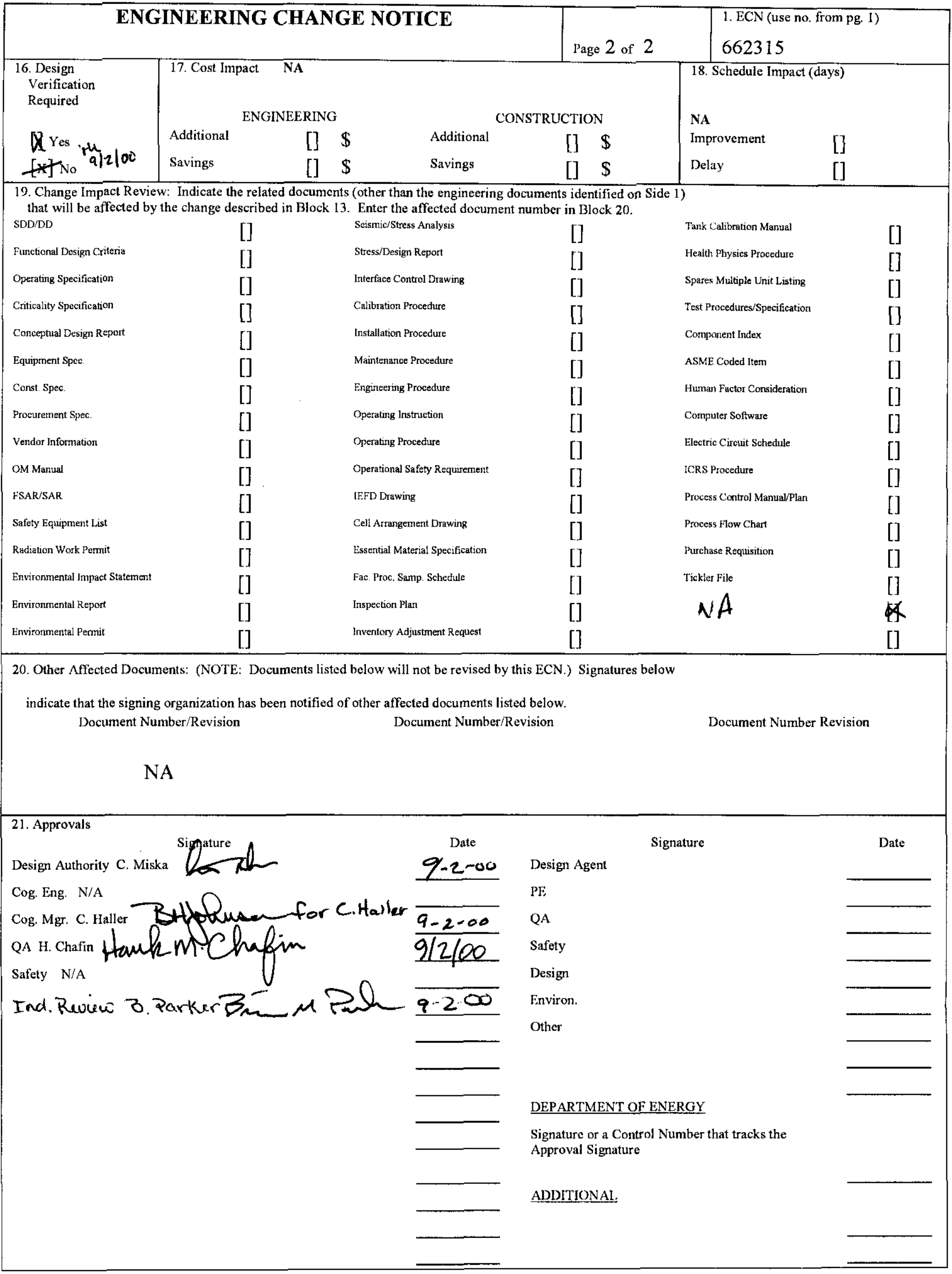


DISTRIBUTION SHEET

To

Distribution

Project TitleNork Order

W-441, P5 CGI Packages Edituicillchenges.
From

$\mathrm{SNF}-\mathrm{CVD}$
Page 1 of 1

Date $9 / 2 / 00$

EDT No.

ECN No. 662315

Name

D. Whitehurst

G. Singh

CVD Library

R. Ramsgate

J. Brehm

P. Beaudet

P. Morrell (AVS)

C. Miska

L. Price

SNF Startup

SNE Project Files

SNF Satelite Library

C. Van Katwijk

D. Whitworth

T. Nuxall \begin{tabular}{c|c|c} 
Text & & Attach./ \\
With All & Text Only & Appendix
\end{tabular}

With All Text Only

Attach.
EDT/ECN Only 
SNF-3932

Revision 4

\section{Whitey/Swagelok SCHe Ball Valves - Provide Isolation Between SCHe Purge Lines C And D And The Process Vent}

Prepared for the U.S. Department of Energy

Assistant Secretary for Environmental Management

Project Hanford Management Contractor for the

U.S. Department of Energy under Contract DE-AC06-96RL13200

Fluor Hanford

P.O. Box 1000

Richland, Washington 
SNF-3932

Revision 4

ECN 662315

\section{Whitey/Swagelok SCHe Ball Valves - Provide Isolation Between SCHe Purge Lines C And D And The Process Vent}

Project No: W-441

C Miska

$\mathrm{FH}$

Date Published

September 2000

Prepared for the U.S. Department of Energy

Assistant Secretary for Environmental Management

Project Hanford Management Contractor for the

U.S. Department of Energy under Contract DE-AC06-96RL13200

\section{Fluor Hanford}

P.O. Box 1000

Richland, Washington
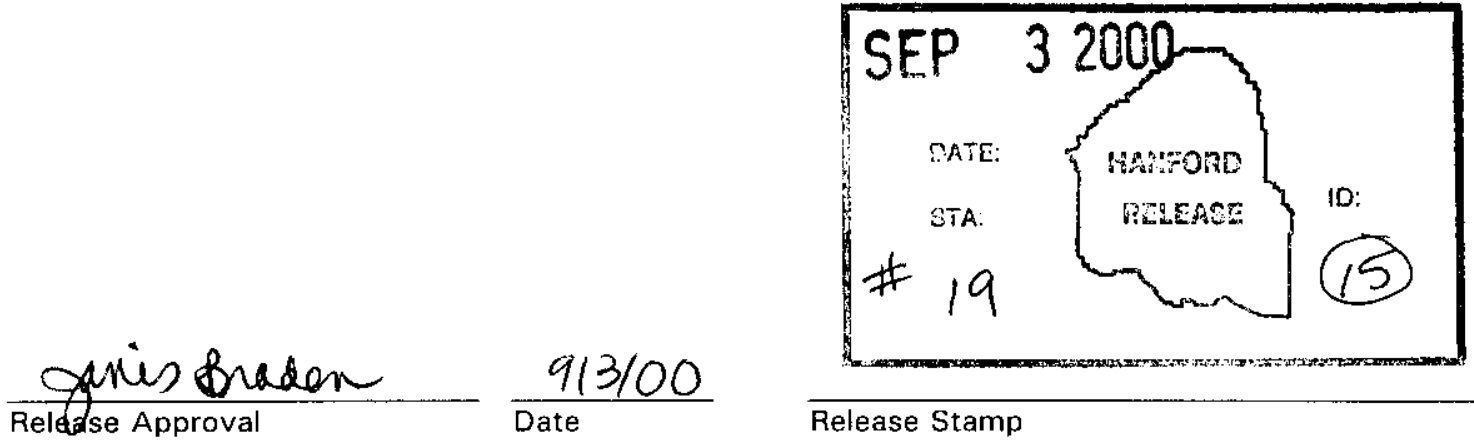

Release Stamp 
SNF - 3932

ReN 4

TRADEMARK DISCLAIMER

Reference herein to any specific commercial product, process,

or service by trade name, trademark, manufacturer, or

otherwise, does not necessarily constitute or imply its

endorsement, recommendation, or favoring by the United

States Government or any agency thereof or its contractors or subcontractors.

This report has been reproduced from the best available copy.

Printed in the United States of America

Total Pages: $\quad 14$ 


\section{RECORD OF REVISION}

(1) Document Number

$S N F-3932$

Page 1

(2) Title

WHITEY/SWAGELOK SCHE BALL VAZVES - PROVIDE ISOLATION BETWEEN SCHE PURGE LINES C AND D AND THE PROCESS VENT

Change Control Record

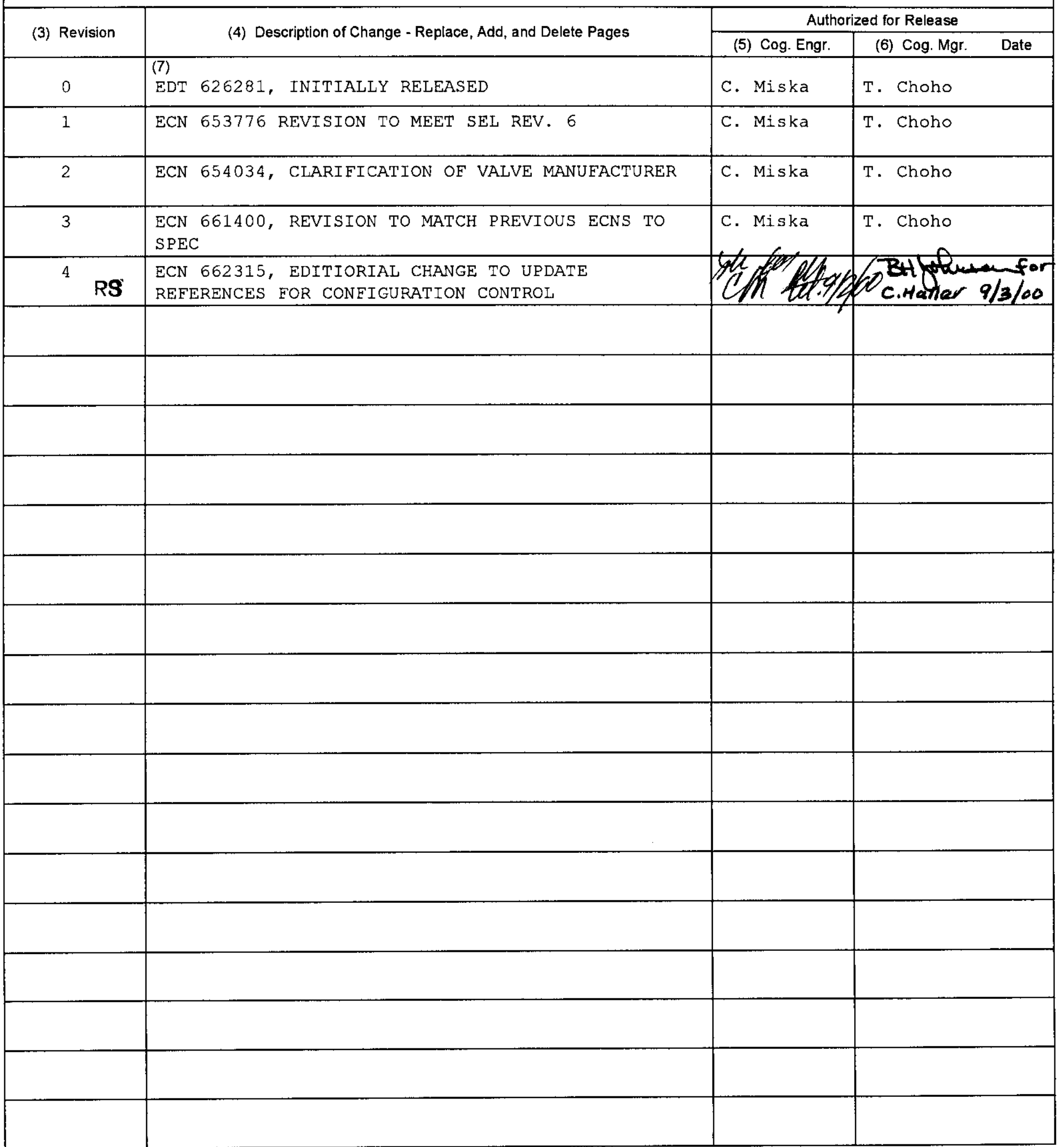




\begin{tabular}{|l|l|}
\hline Commercial Grade Item Upgrade Dedication Form & SNF-3932, Rev. 4 \\
\hline ECN No. NA & Page 1 of 10 \\
Title: WHITEY/SWAGELOK SCHe BALL VALVES - PROVIDE & \\
$\begin{array}{l}\text { ISOLATION BETWEEN SCHe PURGE LINES C AND D AND THE } \\
\text { PROCESS VENT }\end{array}$ & \\
\hline
\end{tabular}

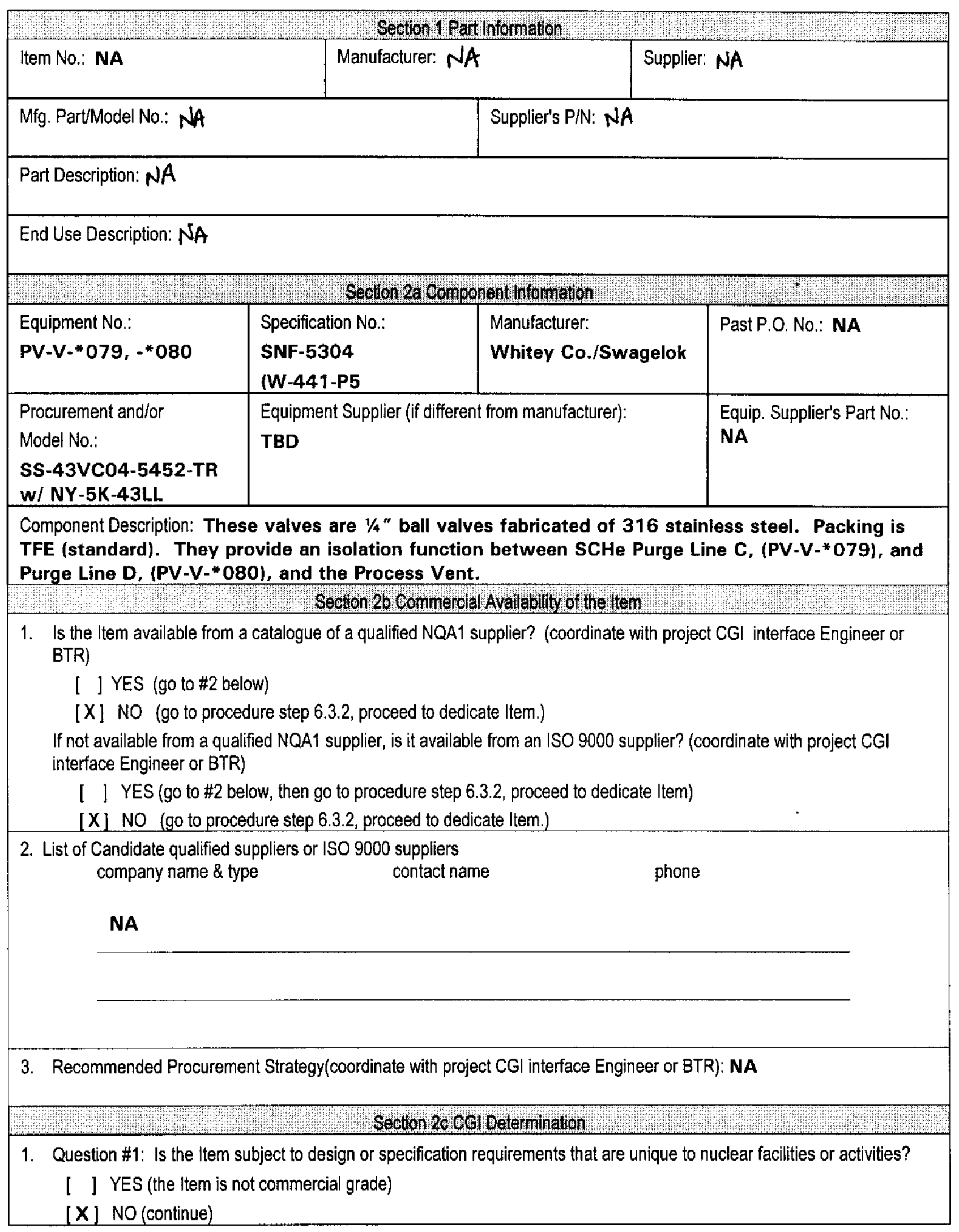




\begin{tabular}{|l|l|}
\hline Commercial Grade Item Upgrade Dedication Form & SNF-3932, Rev. 4 \\
\hline ECN No. NA CGI No. CGI-SNF-D-30-P5-036 & Page 2 of 10 \\
Title: WHITEY/SWAGELOK SCHe BALL VALVES - PROVIDE & \\
$\begin{array}{l}\text { ISOLATION BETWEEN SCHe PURGE LINES C AND D AND THE } \\
\text { PROCESS VENT }\end{array}$ & \\
\hline
\end{tabular}

2. Question \#2: Is the Item used in applications other than nuclear facilities or activities?

[ ] NO (the item is not commercial grade)

[X] YES (continue)

3. Question \#3: Is the ltem ordered from manufacturer/supplier on the basis or specifications set forth in the Published product information (e.g., manufacturer's catalog)?

[ ] NO (the Item is not commercial grade)

$[\mathbf{X}]$ YES (continue)

[X] All three criteria have been satisfied. The ltem meets the definition of commercial grade.

The above described lten is being Bedicated for use in the applicatlon cited for the following reason(s):

[ ] Item is being purchased from a non ESL manufacturer supplier as commercial grade to be used in a Safety Class application.

[X ] Item is being purchased from a non ESL manufacturer supplier as commercial grade to be used in a Safety Significant application.

[ ] Item was purchased from a non ESL manufacturer supplier as commercial grade to be used in a Safety Class application.

[ ] Item was purchased from a non ESL. manufacturer supplier as commercial grade to be used in a Safety Significant application.

[ ] Other ('like-for-like', similar, substitution, replacement evaluation) Section 3 Failure Effects Evaluation

A. Part/Component Safety Function:

1. Prevent $\mathrm{H}_{2}$ Explosion, by not restricting flow.

2. Provide Seismic $3 / 1$ protection for adjacent SC and SS SSCs.

B. Part/Component Functional Mode:

Safety Function \#1:

[ ] Active - Mechanical or Electrical change of state is required to occur for the component to perform its safety function

[X] Passive - Change of state is not required for the component to perform its safety function

Safety Function \#2:

[ ] Active - Mechanical or Electrical change of state is required to occur for the component to perform its safety function.

[X] Passive - Change of state is not required for the component to perform its safety function Safety Function \#3:

[ ] Active - Mechanical or Electrical change of state is required to occur for the component to perform its safety function.

1 Passive - Change of state is not required for the component to perform its safety function

C. Host Component Safety Function (if applicable): NA

1. 


\begin{tabular}{|l|l|}
\hline Commercial Grade Item Upgrade Dedication Form & SNF-3932, Rev. 4 \\
\hline ECN No. NA CGI No. CGI-SNF-D-30-P5-036 & Page 3 of 10 \\
Title: WHITEY/SWAGELOK SCHe BALL VALVES - PROVIDE & \\
\hline ISOLATION BETWEEN SCHe PURGE LINES C AND D AND THE & \\
\hline PROCESS VENT & \\
\hline
\end{tabular}

D. Failure Mode(s) and the effects on component or system safety function (see Worksheet 1):

1. Valve Body Break. Could cause release of helium into the local environment instead of going to the process vent.

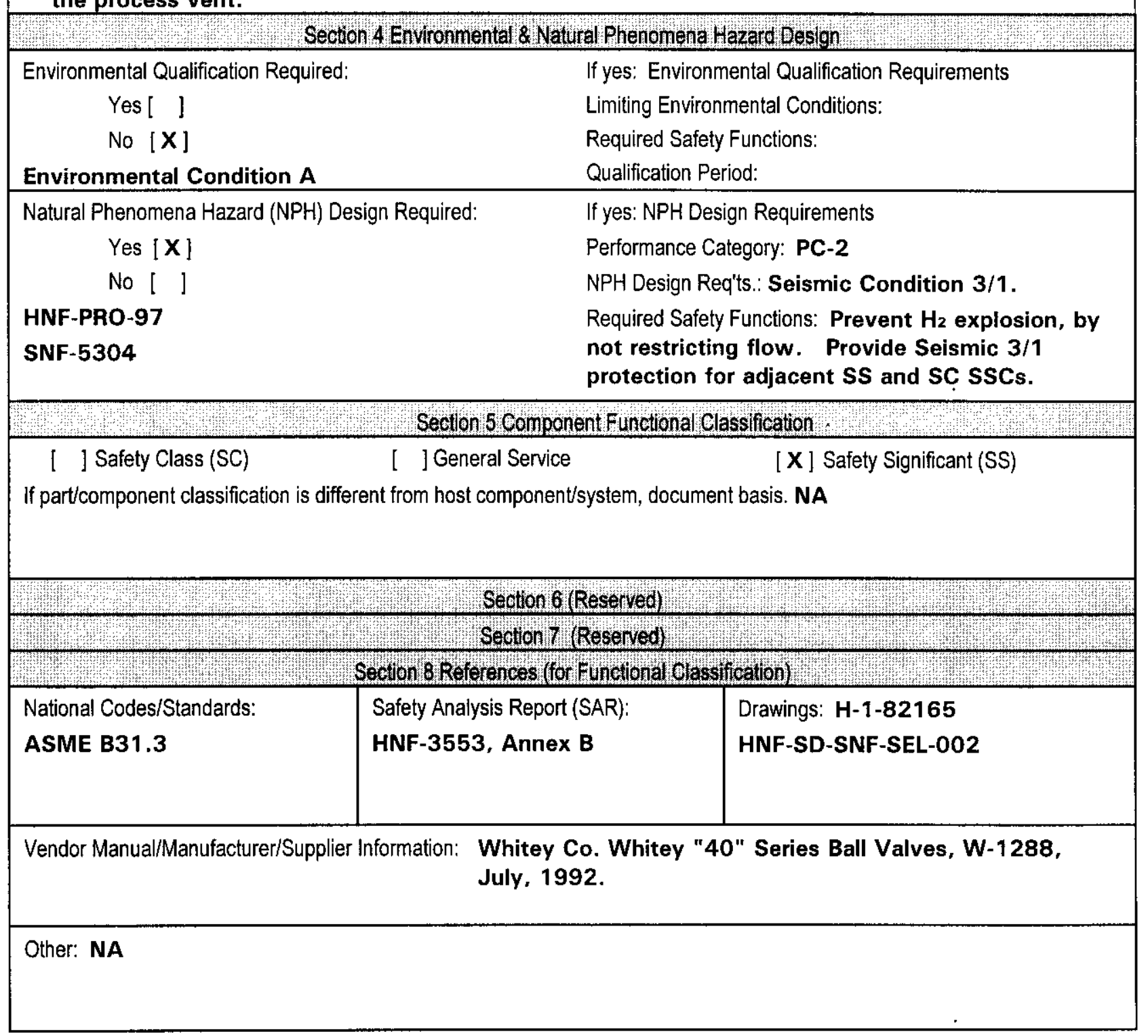




\begin{tabular}{|l|l|}
\hline Commercial Grade Item Upgrade Dedication Form & SNF-3932, Rev. 4 \\
\hline ECN No. NA CGI No. CGI-SNF-D-30-P5-036 & Page 4 of 10 \\
Title: WHITEY/SWAGELOK SCHe BALL VALVES - PROVIDE & \\
$\begin{array}{l}\text { ISOLATION BETWEEN SCHe PURGE LINES C AND D AND THE } \\
\text { PROCESS VENT }\end{array}$ & \\
\hline
\end{tabular}

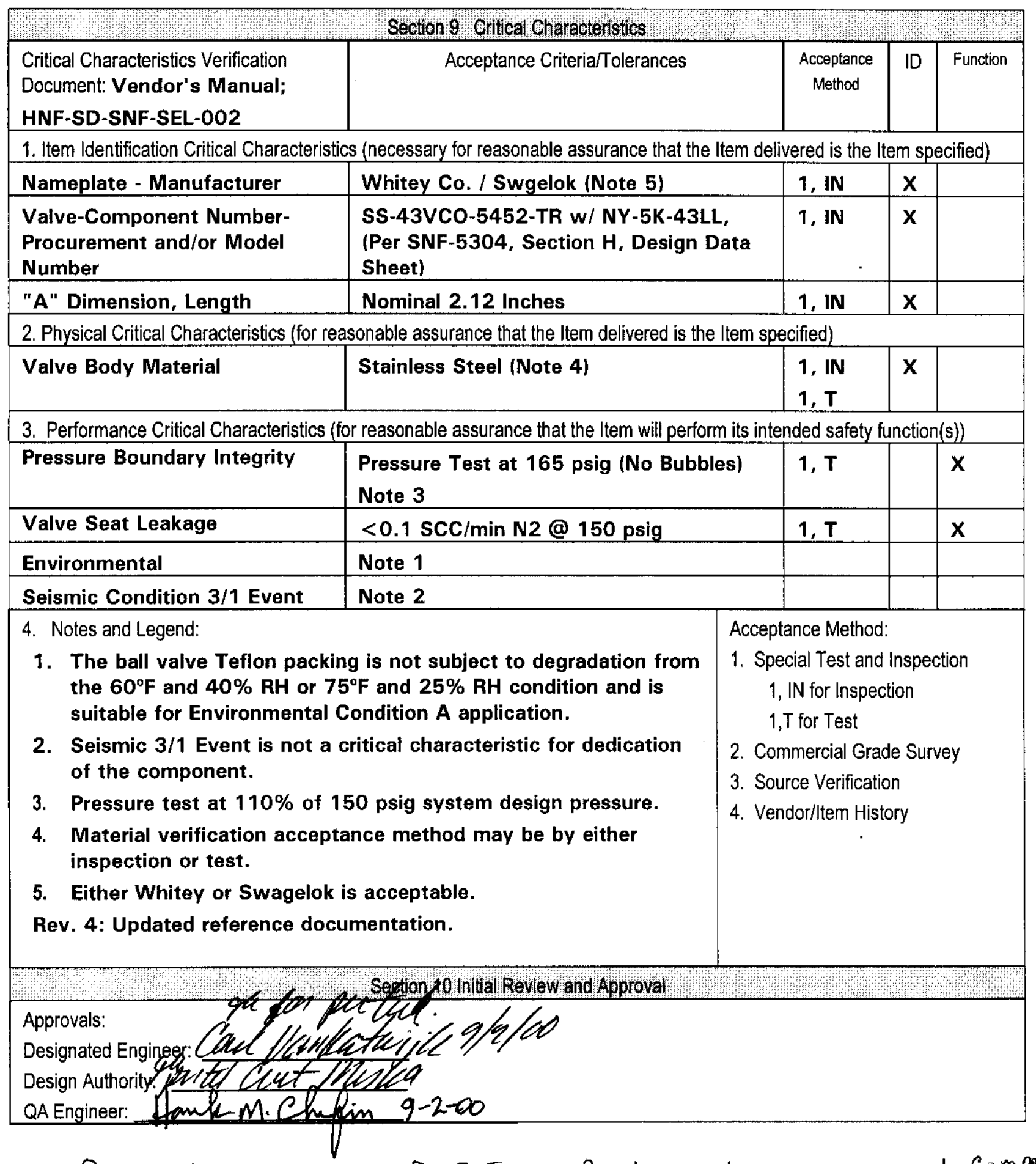

Tefion trademark of E.I. dy Pont de hemours and comping (JUB a $13 / 00)$ 


\begin{tabular}{|l|l|}
\hline Commercial Grade Item Upgrade Dedication Form & SNF-3932, Rev. 4 \\
\hline ECN No. NA CGI No. CGI-SNF-D-30-P5-036 & Page 5 of 10 \\
Title: WHITEY/SWAGELOK SCHe BALL VALVES - PROVIDE & \\
$\begin{array}{l}\text { ISOLATION BETWEEN SCHe PURGE LINES C AND D AND THE } \\
\text { PROCESS VENT }\end{array}$ & \\
\hline
\end{tabular}

\begin{tabular}{|c|c|c|}
\hline \multicolumn{3}{|c|}{$\begin{array}{c}\text { WORKSHEET } 1 \\
\text { DETERMINATION OF FAILURE MECHANISMSIMODES }\end{array}$} \\
\hline \multicolumn{3}{|c|}{ SECTION 1} \\
\hline $\begin{array}{l}\text { Typical Failure } \\
\text { Mechanisms }\end{array}$ & Definition & $\begin{array}{l}\text { Applicable to Component } \\
\text { under Evaluation }\end{array}$ \\
\hline Fracture & $\begin{array}{l}\text { Separation of a solid accompanied by little or no } \\
\text { macroscopic plastic deformation. }\end{array}$ & $\begin{array}{l}\text { Yes [ ] No [ } \mathrm{X} \text { ]; If Yes, indicate failure } \\
\text { Mode }\end{array}$ \\
\hline Corrosion & $\begin{array}{l}\text { The gradual deterioration of a material due to } \\
\text { chemical or electrochemical reactions, such as } \\
\text { oxidation, between the material and its environment. }\end{array}$ & $\begin{array}{l}\text { Yes [ ] No [ X ]; If Yes, indicate failure } \\
\text { Mode }\end{array}$ \\
\hline Erosion & $\begin{array}{l}\text { Destruction of materials by the abrasive action of } \\
\text { moving fluids, usually accelerated by the presence } \\
\text { of solid particles carried with the fluid. }\end{array}$ & $\begin{array}{l}\text { Yes [ ] No [X ]; If Yes, indicate failure } \\
\text { Mode }\end{array}$ \\
\hline Open Circuit & $\begin{array}{l}\text { An electrical circuit that is unintentionally broken so } \\
\text { that there is no complete path for current flow. }\end{array}$ & $\begin{array}{l}\text { Yes [ ] No [X ]; If Yes, indicate failure } \\
\text { Mode }\end{array}$ \\
\hline Short Circuit & $\begin{array}{l}\text { An abnormal connection by which an electrical } \\
\text { current is connected to ground, or to some }\end{array}$ & $\begin{array}{l}\text { Yes [ ] No [X ]; If Yes, indicate failure } \\
\text { Mode }\end{array}$ \\
\hline Blockage & $\begin{array}{l}\text { Clogging of a filtering medium resulting in the } \\
\text { inability to perform its purification function or } \\
\text { blockage of flow. }\end{array}$ & $\begin{array}{l}\text { Yes [ ] No [X]; If Yes, indicate failure } \\
\text { Mode }\end{array}$ \\
\hline Seizure & $\begin{array}{l}\text { Binding of a normally moving item through excessive } \\
\text { pressure, temperature, friction, jamming. }\end{array}$ & $\begin{array}{l}\text { Yes [ ] No [X]; If Yes, indicate failure } \\
\text { Mode }\end{array}$ \\
\hline $\begin{array}{l}\text { Unacceptable } \\
\text { Vibration }\end{array}$ & $\begin{array}{l}\text { Mechanical oscillations produced are beyond the } \\
\text { defined permissible limits due to unbalancing, poor } \\
\text { support, or rotation at critical speeds. }\end{array}$ & $\begin{array}{l}\text { Yes [ ] No [X ]; If Yes, indicate failure } \\
\text { Mode }\end{array}$ \\
\hline Loss of Properties & $\begin{array}{l}\text { A loss of mechanical and physical properties of a } \\
\text { material due to exposure to high temperatures, } \\
\text { radiation exposure. }\end{array}$ & $\begin{array}{l}\text { Yes [ ] No [X]; If Yes, indicate failure } \\
\text { Mode }\end{array}$ \\
\hline Excess Strain & $\begin{array}{l}\text { Under the action of excessive external forces the } \\
\text { material of the part has been deformed or distorted. }\end{array}$ & $\begin{array}{l}\text { Yes [ ] No [X]; If Yes, indicate failure } \\
\text { Mode }\end{array}$ \\
\hline Mechanical Creep & $\begin{array}{l}\text { From prolonged exposure to high temperature and } \\
\text { stress, the object will show a slow change in its }\end{array}$ & $\begin{array}{l}\text { Yes [ ] No [X ]; If Yes, indicate failure } \\
\text { Mode }\end{array}$ \\
\hline Ductile Fracture & $\begin{array}{l}\text { characteristics. } \\
\text { Fracture characterized by tearing of metal } \\
\text { accompanied by appreciable gross plastic } \\
\text { deformation. }\end{array}$ & $\begin{array}{l}\text { Yes [ ] No [ } X \text { ]; If Yes, indicate failure } \\
\text { Mode }\end{array}$ \\
\hline & ction 2 Additlonal Failure Modes Applicabl & Under E \\
\hline 1. & & \\
\hline
\end{tabular}




\begin{tabular}{|l|l|}
\hline Commercial Grade Item Upgrade Dedication Form & SNF-3932, Rev. 4 \\
\hline ECN No. NA CGI No. CGI-SNF-D-30-P5-036 & Page 6 of 10 \\
Title: $\begin{array}{l}\text { WHITEY/SWAGELOK SCHe BALL VALVES - PROVIDE } \\
\begin{array}{l}\text { ISOLATION BETWEEN SCHe PURGE LINES C AND D AND THE } \\
\text { PROCESS VENT }\end{array}\end{array}$ & \\
\hline
\end{tabular}

\section{CHECKLIST 1}

ACCEPTANCE METHOD 1

SPECIAL TEST/INSPECTION VERIFICATION

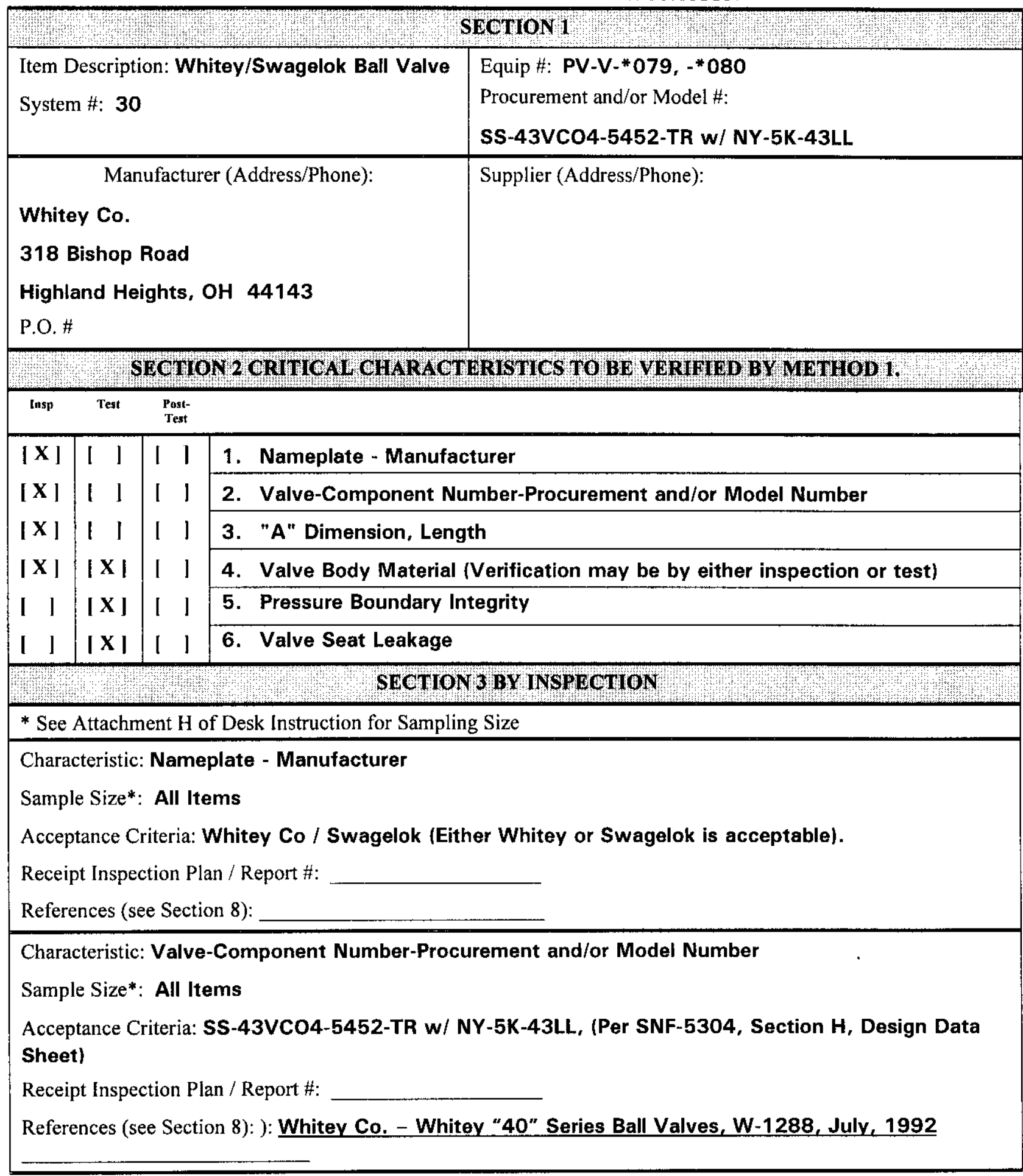




\begin{tabular}{|l|l|}
\hline Commercial Grade Item Upgrade Dedication Form & SNF-3932, Rev. 4 \\
\hline ECN No. NA CGI No. CGI-SNF-D-30-P5-036 & Page 7 of 10 \\
Title: WHITEY/SWAGELOK SCHe BALL VALVES - PROVIDE & \\
\hline $\begin{array}{l}\text { ISOLATION BETWEEN SCHe PURGE LINES C AND D AND THE } \\
\text { PROCESS VENT }\end{array}$ & \\
\hline
\end{tabular}

Characteristic: "A" Dimension, Length

Sample Size*: All Items

Acceptance Criteria: Nominal 2.12 Inches

Receipt Inspection Plan / Report \#:

References (see Section 8):

Characteristic: Valve Body Material

Sample Size*: Normal Sampling Size

Acceptance Criteria: Stainless Steel

Receipt Inspection Plan/Report \#:

References (see Section 8):

\section{SECTION 4 BY SPECIAU TEST}

* See Attachment H of Desk Instruction for Sampling Size

\begin{tabular}{|l|l}
\hline Test To Be Performed by: & Number of Items to be Tested:
\end{tabular}

[ ] Purchaser

[ ] Supplier/Manufacturer**

Test/Inspection Location:

[ ] Other

Characteristic for Test: Pressure Boundary Integrity

Acceptance Criteria: Pressure Test at 165 psig (No Bubbles)

Sample Size*: Normal Sampling Size

Actual Test Value:

Test Plan and Report \#:

References (see Section 8):

Characteristic for Test: Valve Seat Leakage

Acceptance Criteria: < $0.1 \mathrm{scc} / \mathrm{min}$ N2 @ $150 \mathrm{psig}$

Sample Size*: Normal Sampling Size

Actual Test Value:

Test Plan and Report \#: References (see Section 8):

**If Supplier/Manufacturer or Other, Refer to CGI Checklist-2 for Support Information 


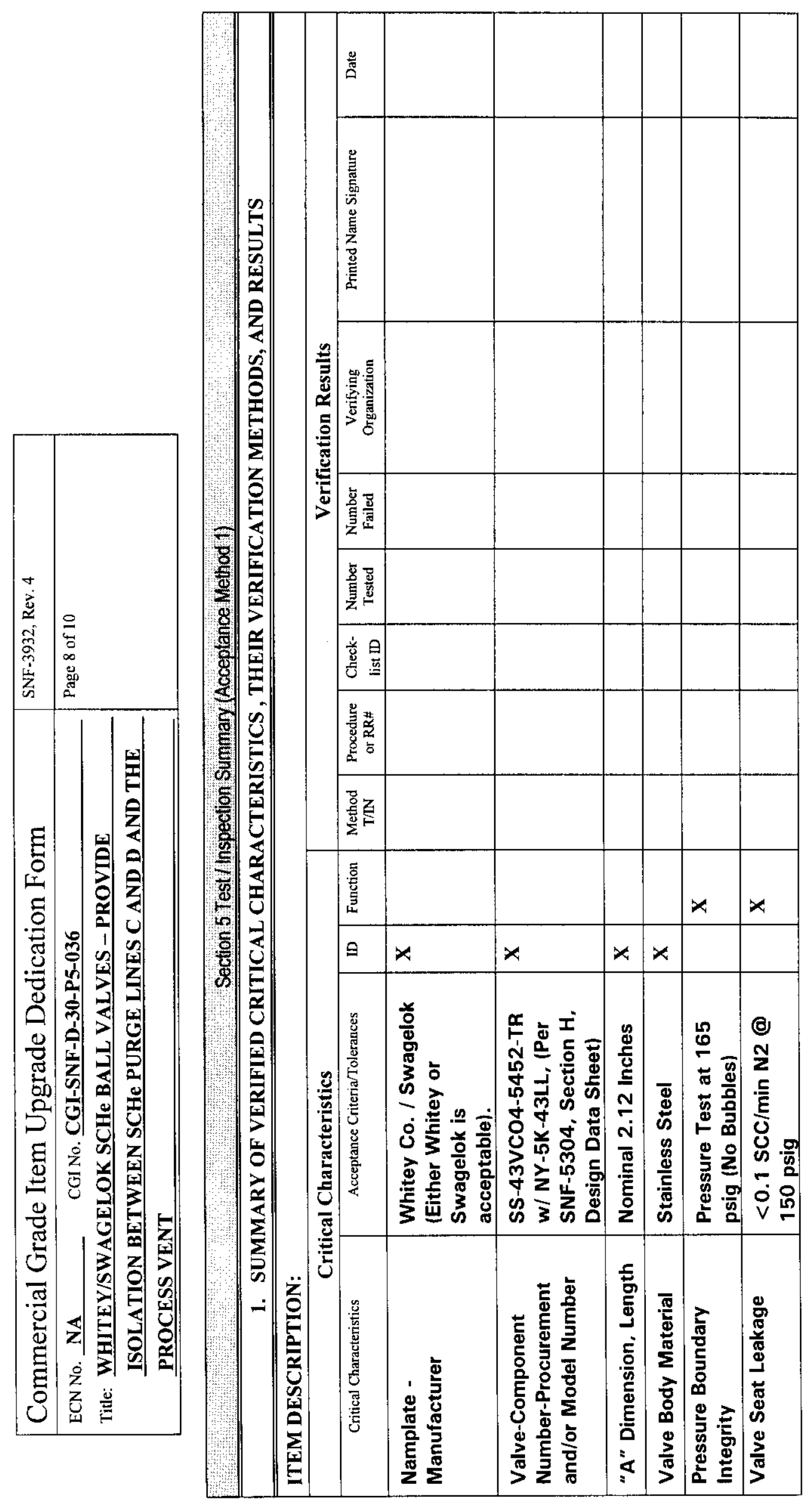




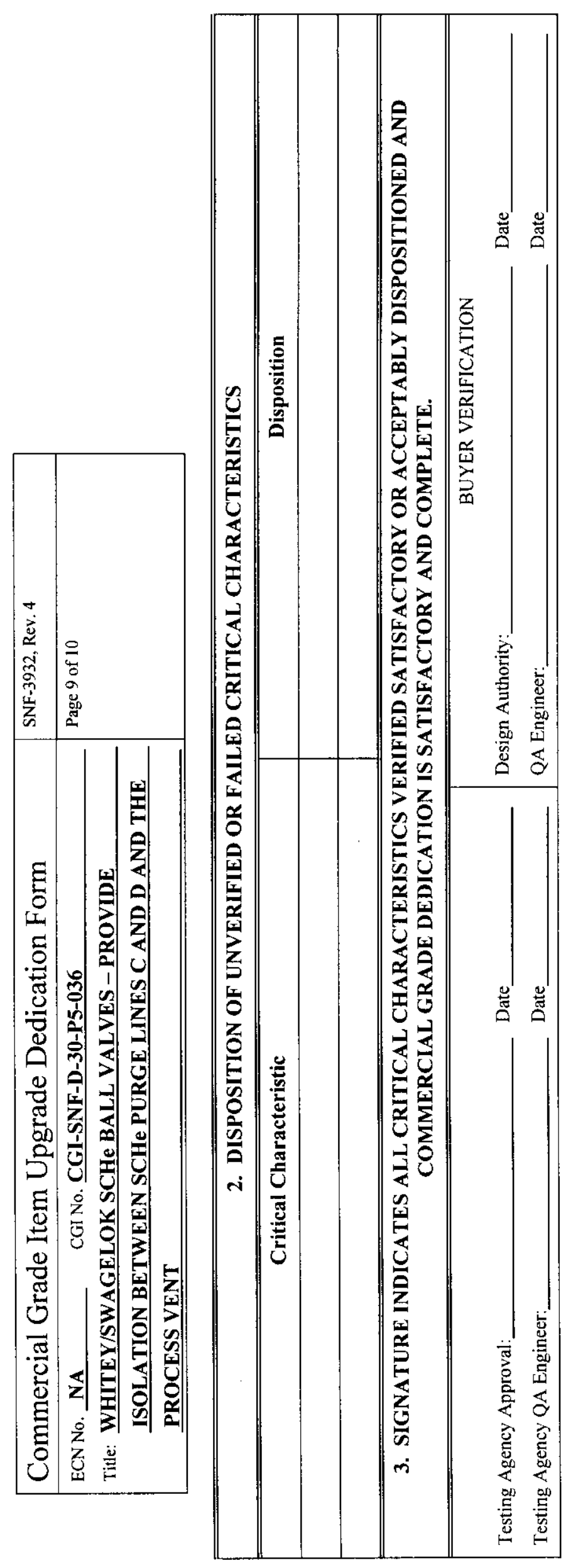

$\stackrel{8}{0}$
ᄋ
8 


\begin{tabular}{|l|l|}
\hline Commercial Grade Item Upgrade Dedication Form & SNF-3932, Rev. 4 \\
\hline ECN No. NA CGI No. CGI-SNF-D-30-P5-036 & Page 10 of 10 \\
Title: WHITEY/SWAGELOK SCHe BALL VALVES - PROVIDE & \\
\hline ISOLATION BETWEEN SCHe PURGE LINES C AND D AND THE & \\
\hline PROCESS VENT & \\
\hline
\end{tabular}

\begin{tabular}{|c|c|c|}
\hline \multicolumn{3}{|c|}{ Section 6 ContactsiRhone Numbers } \\
\hline \multicolumn{2}{|l|}{ Name } & Phone \\
\hline \multicolumn{2}{|l|}{ Design Authority } & ) \\
\hline \multicolumn{2}{|l|}{$\overline{Q A}$} & ) \\
\hline \multicolumn{2}{|l|}{ QC } & ) \\
\hline \multicolumn{2}{|l|}{ Cog - Engineer } & ) \\
\hline \multicolumn{2}{|l|}{ CGI Engineer } & ) \\
\hline \multicolumn{2}{|l|}{ Procurement Engineer } & ) \\
\hline Other & ( & ) \\
\hline \multicolumn{3}{|c|}{ Section 7 Supporting Documentation for this Checklist } \\
\hline \multicolumn{3}{|c|}{\begin{tabular}{|l|l|} 
Initial Procurement Documents & For Critical Characteristics \\
\end{tabular}} \\
\hline \multicolumn{3}{|l|}{ [ ] Drawings: } \\
\hline \multicolumn{3}{|l|}{ [ ] Manuals (specify type \& number): } \\
\hline \multicolumn{3}{|l|}{ [ ] Design Calculations } \\
\hline \multicolumn{3}{|l|}{ [ ] Installation Instructions } \\
\hline \multicolumn{3}{|l|}{ [ ] Operation Instructions } \\
\hline \multicolumn{3}{|l|}{ [ ] Calibration Instructions } \\
\hline \multicolumn{3}{|l|}{ [ ] Manufacturer's Recommended Spare Parts List } \\
\hline \multicolumn{3}{|l|}{ [ ] Other: } \\
\hline \multicolumn{3}{|l|}{ Procurement Documents } \\
\hline \multicolumn{3}{|l|}{ [ ] Certificate of Conformance/Compliance } \\
\hline \multicolumn{3}{|l|}{ [ ] Seismic Qualification Certificate } \\
\hline \multicolumn{3}{|l|}{ [ ] Environmental Qualification Certificate } \\
\hline \multicolumn{3}{|l|}{ [ ] Test Report (s): } \\
\hline \multicolumn{3}{|l|}{ [ ] Inspection Report (s): } \\
\hline \multicolumn{3}{|l|}{ [ ] CMTRs for ASME Pressure Retaining Materials } \\
\hline \multicolumn{3}{|l|}{ [ ] Valve Seat Leakage Report } \\
\hline \multicolumn{3}{|l|}{ [ ] Weld Records } \\
\hline \multicolumn{3}{|l|}{ [ ] Material Traceability Record } \\
\hline [ ] Other: & & \\
\hline
\end{tabular}

